\title{
Meals and Eating Practices within a Multi-generational Approach: A Qualitative Insight Study
}

\section{Christine Brombach}

Zurich University of Applied Sciences, Einsiedlerstrasse 34, CH-8820 Waedenswil, Switzerland

\begin{abstract}
Background: Eating behaviour is predominantly learned in childhood during socialisation, growing up in a cultural context. Various studies suggest that parents play an important role in the patterning of the eating behaviour of children. Very few studies consider the development of meals and eating practices in the context of multi-generational influences, therefore, the aim of this research project was to investigate influences on eating behaviour in one multi-generational family, presently living in South-West Germany. The parents, first generation (F1), were born at the end of 19th century. The couple had 15 children, the second generation (F2), and two of those children are alive today. There are 31 grandchildren (F3) and 50 great grand children (F4) and currently more than 10 great grand children (F5). The purpose of this study was to gain insights into the onset of eating behaviour and eating practices within a single multigenerational family perspective.

Methods: This study is a single case study of a multi-generational family living in South-West Germany. Qualitative interviews with an aide-mémoire were used within the matrilineal branch of the family, tracing four generations and spanning a time frame of three centuries.

Results: The predominant role of women in meal preparation, use of family recipes, customs and food practices can be traced into the F4 generation. It appears that the matrilineal dissemination of meal structures and opinions, family recipes, use of cherished cookbooks, customs, is stronger than in the patrilineal mode and can be traced to the $\mathrm{F} 4$ in the present.

Conclusion: To date very few studies have been conducted with a three generational, let alone multigenerational, approach on tracing eating practices within one family. The findings permit a better understanding of the onset of eating practices in a broader familial and cultural historical context.
\end{abstract}

\section{Introduction}

We humans must feed our body with food, eating is inevitable and necessary for our survival. However, unlike many animals, we do not have any instincts or reflexes that guide us to what, when, and how to eat, and with whom [1-5]. We have to learn to eat. Eating behaviour is acquired while growing up within a certain environment in a familial, cultural, social and historical context. Our individual eating habits, therefore, reflect the routines and habits of the social group we belong to $[1,6-11]$.

Babies are usually provided with food by their mothers/carers and learn that feeding occurs periodically, with specific foods and in certain manners. The baby's carer usually relies on her own (childhood) experience or knowledge from relatives, thereby repeating certain habits and patterns and carrying on established eating habits of a certain family/social group [10,12-15].The eating behaviour is copied by babies and infants from their caregivers thus mirroring the food practices and food traditions of the primary social group [16-19].

Studies on eating and eating behaviour are predominantly carried out within the framework of a natural scientific perspective; however, a social science approach provides answers on "why" we eat what we do and provides "understandings" of and "insights" into the mechanisms of "why we eat what we eat" [20-24]. Nutrition behaviour is "the sum of all planned, spontaneous, or habitual actions of individuals or social groups to procure, prepare, and consume food, as well as those actions related to storage and clearance. In this context, the term 'nutritional behaviour' not only refers to influencing factors but also to health, environmental, social, and economic implications along the entire product chain from farmer to consumer" [25].

\section{Publication History:}

Received: July 24, 2017

Accepted: September 11, 2017

Published: September 13, 2017

\section{Keywords:}

Nutritional behaviour, Food practices, Eating biography, Multigenerational families, Food culture, Contextual influences

\section{Why do we eat what we do?}

All humans eat to stay alive, while they live (or are fed to stay alive). Determinants of eating behaviour can be broken down into very fundamental aspects that are prerequisite and universal in all human cultures: person(s), area, time, aims, food, and general belief. These determinants fit together like a jigsaw puzzle as depicted in figure 1 .

Eating is always connected to a person or persons, each person feeds his/her own body and eating cannot be delegated. Furthermore, a person or persons are always connected to certain areas, places, rooms or regions where certain foods are consumed. Persons eat at specific times, such as daytime, seasonal time, historical time, persons eat according to certain aims and reasons, and each culture defines what it considers as food and what is or is not edible. Certain items might therefore be highly regarded in one culture whereas detested or regarded as taboo in another [26-30]. Insects, for example, are highly treasured in Asian countries while most European countries permit insects with restrictions. What we and other persons eat is determined according to various rationales: belief systems, religions and values. Pork and alcohol, for example, are forbidden in the Jewish and Islamic religions, while permitted in the Christian faith. As depicted in figure 1,

"Corresponding Author: Dr. Christine Brombach, Zurich University of Applied Sciences, Einsiedlerstrasse34, CH-8820 Waedenswil, Switzerland; E-mail: christine.brombach@zhaw.ch

Citation: Brombach C (2017) Meals and Eating Practices within a Multigenerational Approach: A Qualitative Insight Study. Int J Clin Nutr Diet 3: 122. doi: https://doi.org/10.15344/2456-8171/2017/122

Copyright: (c) 2017 Brombach. This is an open-access article distributed under the terms of the Creative Commons Attribution License, which permits unrestricted use, distribution, and reproduction in any medium, provided the original author and source are credited. 
these basic determinants are summarised as the "eating model", where the sum of the individual pieces constitutes a picture of eating behaviour:

- $\quad(E)$, everybody, individual person(s)

- $\quad(A)$, areas, regions, rooms

- (T) time, seasons, history

- (I) aims, reasons

- $\quad(N)$ nourishment, food

- (G) general beliefs, values

Eating takes place in individual settings, the so called microlevel, however, eating is also connected to certain ambiences, the mesolevel, i.e. eating is connected to a region, and to a cultural historical context, the macro level,for example, a certain territory or country [31-35].

Mothers are responsible for the transmission of food knowledge, eating practices and family recipes, as well as (mostly) for maternal dissemination of family traditions and family histories [36-39]. In a recent study by Brombach et al. [5] in a three generational approach, it was found that frequency of consumption changes during the course of a lifetime and over three generations for some food groups, whereas for other food groups, there were no changes. In the same study the authors concluded that the grandmother generation grade their cooking skills better as parents or children. Grandparents have a better mastering of using food leftovers than their grandchildren.

Some studies report that eating practices and food preferences in childhood are maintained throughout adulthood and what children have learned in respect to eating patterns will be carried into their later lives [15, 40-43].

\section{Objectives}

The aim of this case study was to investigate whether food practices and eating behaviours are passed down along generations and how. A single case study within a multi-generational approach was set up to gain insights in transmission patterns in a single family. Ideally such a study should explore a multi-generational family with members living primarily in a common area and in close proximity.

\section{Materials \& Method}

While quantitative methods pursue identification on "cause and effect mechanisms", qualitative methods focus primarily on the complexity and variety of individuals' everyday life situations [8, $20,21,44]$. In this study, an aide-mémoire with open-ended themes was applied to obtain narratives, descriptions and insights into the eating behaviour and eating practices of the interviewees. The aidemémoire addressed the sequences of childhood (up to about 10-12 years), teenage period (until about 18 years) and young adulthood, the present, thereby capturing course of life and cultural context of interviewees. The aide-mémoire covered the following themes: meal situations, meal preparation and responsibilities, cooking, shopping, preserving food, gardening, family recipes, role of male family members, economic situations, opinions on foods and traditions, favourite meals and festive activities. Questions were asked in an open-ended manner and questions and answers were recorded. Interview themes were grouped and analysed according to Mayring [21]. It was not the aim of this case study to produce representative results.

A multi-generational family was approached via an intermediary and a relationship was established. Five qualitative interviews were carried out with daughter Laura (F2), born in 1926 as 14th child of Martha (1885-1957) and her husband Michael (1877-1954); with Laura's daughter Susanne (F3), born in 1960, Susanne's daughter Alexa (F4), born in 1988; and grandson Gerhard (F3), born in 1937, son of Martha's 4th child (1910-1971) and Hillary (F3), born 1954, daughter of Martha's 15th child. In addition, written questionnaires were sent to family members (study still ongoing, results not shown here).The questionnaires contained questions with blocks of subquestions on the frequency of intake of selected foods, meal patterns, cooking, food purchase, storage, handling, attitudes to nutrition, both today and (where appropriate) during childhood.

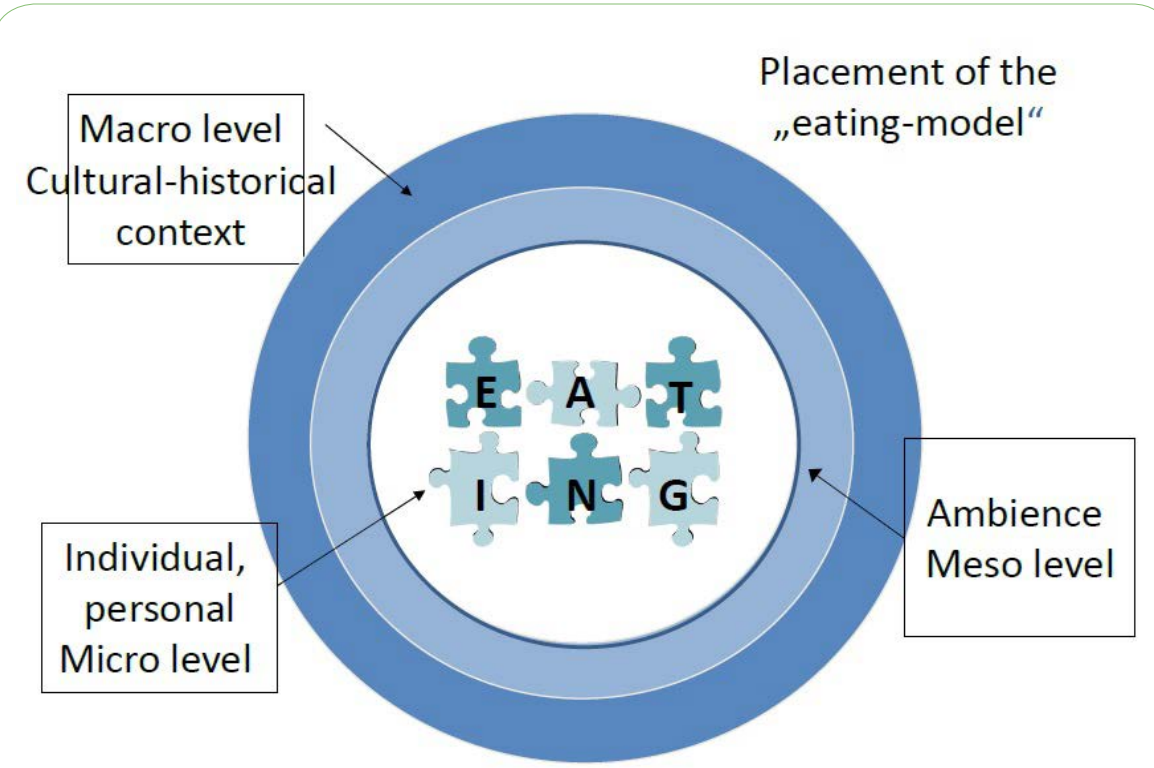

Figure 1: The eating model, modified according to Brombach, 2015, 20 [52]. 


\section{Results}

Interviews took place in the home of the individual interviewees or in a place outside the home with interviews lasting between 1 and 2 hours; with Laura a total of 3 interviews were conducted, each approximately 2 hours in length.

Laura's mother Martha was born in 1885 and died in 1957 (F1); her daughter Laura was born in 1926 (F2); she is now 92 years old and lives in an old people's home (at time of interview, March-July 2017). Laura has five children, three boys and two daughters. Susanne, Laura's older daughter (F3) has four children, three boys and one daughter, Alexa (F4). Martha's granddaughter Hillary (F3) has no children; Gerhard (F3) has three children and four grandchildren. All interviewees were brought up in South-West Germany. Martha grew up at the end of the 19th century in a setting, which was still influenced by the German Empire. She was born 14 years after the foundation of the Empire, in a very different political, economic and technological system from her granddaughter's present situation. Martha spent her young adulthood and started her own family during World War I, she experienced World War II in her mid-50's during which she lost one son on the battlefield, her house was destroyed during bombing and as an old woman she experienced the foundation and separation of Germany, the Federal Republic of Germany and the German Democratic Republic. She raised 15 children, born between 1907 and 1929. Her daughter Laura lived through various political systems, food shortages, new technological development and profound changes in food production, as well as industrialisation of farming systems. Laura also experienced a radical change in food availability and modification in food shops from a system of being served to self-service, from monetary systems to online payment and the use of credit cards, the availability of global foods on the market, and the rise of an affluent society from the mid 60's with today's food security and availability of food $24 \mathrm{~h}$ a day, 7 days a week.

\section{Cooking}

Martha had learned cooking from her mother and from her time as a young housemaid in a bourgeois household before she got married when 19 years old. She trained all her daughters how to cook but not her sons. In this family, cooking was done by Martha and her daughters, they had a large garden where food was grown and many foods were preserved at home. It was the duty of the daughters to assist their mother with the daily chores. Martha trained her daughters well, her oldest daughter, who never got married, had the overview of the kitchen and the assistance provided by the younger daughters. Laura recalled her older sister's strict regime: "she always decided what we had to do. We always had to do the scrubbing, cleaning, washing up [...], but she was an excellent cook and made the best potato salad" [Laura].

\section{Cookery book}

In 1932 a Swabian (South West German) cookery book was published: its themes covered basic recipes and instructions of how to cook in a housewifely, resourceful and economic way [45]. Although Martha had learned cooking from her mother and her time as a housemaid, she was eager to improve her knowledge on recipes and ideas on how to cook healthily and economically for her family. She used this cookery book extensively and gave all her daughters a copy of this book upon their marriage. Laura also used this cookery book, which currently is published in its $56^{\text {th }}$ edition. Laura also provided her daughters with this cookery book and Susanne, as well Alexa, still use it nowadays. Hillary reported: “...you mean my favourite cookery book? It is Luise Haarer's Kochen und Backen nach Grundrezepten (Basic recipes in cooking and baking) which I still use today; I got a copy from my mother" [15th child of Martha]. Laura reported that in her childhood, cooking started in the mornings, sometimes even the previous evening before, and included chores such as peeling potatoes and covering them with water to prevent them going brown before cooking.

The cookery book was passed down in this family and is still used by the grandchildren and great grandchildren. As the interviews revealed: basic and "key recipes" are adhered to up to the present, thereby continuing a special local South West German cooking style, such as soups which Martha cooked fresh every day, dumplings and a special dish called "Spaetzle", which is a kind of pasta, made from a dough of eggs, flour, water and salt, with the thick dough being cooked by being scraped from a wooden board directly into boiling water.

\section{Kitchen stove, electrical devices}

Martha initially used a wood stove, later a stove fired by gas; electricity for lighting was first provided in the 1920's. Laura reported that in her childhood her family was the only household in the street with a telephone and a car, due to her father's business as a craftsman. Martha grew vegetables, salads and fruits including berries and apples in the garden. She preserved the food with the aid of her daughters using common methods including fermenting foods, such as sauerkraut, canning, drying or storing foods like beets in the cellar. Laura had a garden as well and trained her daughters (but not her sons) in fermenting foods; she baked bread and made preserves from her garden harvests like Martha. In contrast to her mother, Laura had a deep freezer which she used extensively. Her daughter, Susanne, and granddaughter, Alexa, took over the skills of their (great) grandmother, Laura, and both bake bread, make preserves and like to cook.

\section{Special dishes}

Susanne reported that for Christmas dinner in 2016 she cooked roasted goose, red cabbage, dumplings, chicken broth with dumplings, just as she had learned from her mother, Laura, who herself was taught this tradition by her mother, Martha. Whereas Martha made fresh soups every day, Laura did not continue this tradition; however, Laura cooked meat on Sundays like her mother, Martha. Meat consumption was moderate in Martha's family; meat was expensive and carefully portioned: first the husband, then the sons and finally the mother and daughters were served portions of decreasing size. Laura carefully portioned meat as well, meat was divided at the table in a similar manner such that the husband received the largest portion and the children according to age received less (not gender, as in Martha's home). Meat-based menus were served in Laura's home no more than twice a week, due to economically reasons, "we could not afford meat every day, we lived on my husband's earnings and we had five children..." [Laura].

\section{Gardening}

Martha bought all food locally and in season since nothing else was available in her days. Food was also bought from local farmers and grown in the garden, which was then eaten. As Laura stated: "we ate and cooked what we grew in our garden during my childhood, we 
had no convenience food...my husband also grew vegetables and fruits which we then didn't have to buy?' Laura's daughter, Susanne, also grows some vegetables and fruits in her garden today but she stated: "we grow what we like to eat in the garden, I just like gardening..."Her planting follows another rationale than her mother's or grandmother's. Whereas Susanne choses to garden as a hobby, gardening was a necessity for Laura and her mother for economic reasons.

\section{Table manners}

The seating plan and order of being served the food was distinct at Martha's table: the father sat at the head of the table with his wife next to him and the youngest child sat next to the parents, Martha served her husband and sons first, then the daughters according to age and herself last, a tradition Laura continued. Martha said grace before the beginning of the meal, Laura's husband also prayed before the meals and in the families of Laura's children, both husbands or wives do.

\section{Timing of the meals}

In Martha's family meals were eaten on regularly basis, breakfast around $7 \mathrm{am}$, lunch at around noon and supper at around $6 \mathrm{pm}$. In between there was a morning break and in the afternoon a "coffee" break (although no coffee was served, just a coffee substitute since coffee was too expensive and hence reserved for Sundays and for guests). Timing was important for Martha and her husband. In Laura's family lunch time was regular as well since Laura's husband came home for lunch in his break before he resumed his work. Her children came home at a different time, so often lunch for Laura extended over a time period of up to two hours: "when one child came for lunch break I sat down with him or her, but sometimes by then I had already eaten but I wanted to keep him or her company...". In Susanne's family cooked lunch was moved to dinner, since her children were absent during the day at school: "we often had our main meal in the evening and I cooked for dinner...". Timing in Susanne's family was flexible and for Susanne's daughter, Alexa, time “...depends on what we are doing and who wants to cook...."
Table 1 summarizes and gives an overview of changes in meal patterns over three generations.

While for Martha, cooking and preparing food was hard manual labour without the use of electrical devices during her young adulthood at the end of the 19th and beginning of the 20th century, her $14^{\text {th }}$ daughter, Laura, grew up in the 30 s and 40 s with both electricity and cars. Both granddaughters (born 1954, 1960) and great granddaughter (born 1988) have different food availability to their grandmother/great grandmother and have never experienced hunger or food insecurity. For them convenience food and convenient "takeaway", global foods being available on an almost $24 \mathrm{~h} / 7$ days a week basis is "normal", whereas in contrast, Martha and Laura experienced severe food shortage and learned to make the most of what little they had. Food waste was never an issue in their lifetime, for them food waste was a sinful behaviour, even more so, since food preparation was such hard labour. Martha and Laura did not question their role as mother and housewife. Whereas Martha married shortly after ending her school education in primary school and spending one year as a housemaid, Laura worked as a secretary until her marriage at age 26. Her daughter, Susanne, and granddaughter, Alexa, as well as Hillary, daughter of Martha's 15th child had a higher education and hold university degrees. Cooking and housework was, in Martha's and Laura's opinion, truly just a task for women. They had a gendered view on the food system; chores related to shopping, cooking, preserving, cleaning and storing food were definitely chores of the females in the family, whereas the males had to be served and cared for. Gerhard, son of Martha's 4th child and oldest living grandson of Martha, said that while he assists his wife in shopping and gardening, cooking is mainly his wife's business. This gendered view on the female work load started to erode in the 60 's, yet remains to this day to a limited extent in Susanne's and Hillary's and but less so in Alexa's generation. Alexa and her partner share the chores and Susanne's youngest son started training as a cook after his graduation from university.

\section{Discussion}

This exploratory, pilot study had the principal aim of gaining insights in possible transmission of eating patterns within a multigenerational family living in South-West Germany. There are therefore

\begin{tabular}{|c|c|c|c|c|}
\hline & F1 (1885-1957) & $F 2(92 y, 89 y)$ & $F 3\left(63 y, 56 y_{f}\right)$ & $F 4(28 y)$ \\
\hline Meals & $\begin{array}{l}\text { - } \quad \text { Regular meals } \\
\text { - Only with family } \\
\text { - } \quad \text { Onup as starter } \\
\text { Only seasonal and } \\
\text { regional food } \\
\text { - Never any food waste } \\
\text { Special dishes on } \\
\quad \text { Sundays }\end{array}$ & $\begin{array}{l}\text { Regular meals } \\
\text { home, sometimes } \\
\text { in restaurants, } \\
\text { mainly traditional } \\
\text { food } \\
\text { Rarely food waste } \\
\text { Some convenience } \\
\text { food }\end{array}$ & $\begin{array}{l}\text { Most of the time } \\
\text { regular meals } \\
\text { Often out of home } \\
\text { eating } \\
\text { International } \\
\text { cooking as well } \\
\text { - Convenience food } \\
\text { - Some food waste }\end{array}$ & $\begin{array}{l}\text { Depends, sometimes } \\
\text { to go, often with } \\
\text { friends } \\
\text { Eating is a value } \\
\text { driven } \\
\text { - International recipes } \\
\text { - Food waste, } \\
\text { sustainability }\end{array}$ \\
\hline Time & $7 a m-12$ noon-6pm & $\begin{array}{l}\text { Always cooked lunch at } \\
\text { around noon }\end{array}$ & $\begin{array}{l}\text { Mostly either cooked } \\
\text { lunch, or cooked } \\
\text { dinner instead }\end{array}$ & Depends \\
\hline Values & $\begin{array}{l}\text { - Cooking is solely } \\
\text { female chore } \\
\text { - Eating and table } \\
\text { manners important } \\
\text { - Children had to be } \\
\text { quiet at table } \\
\text { - Husband's } \\
\text { preferences are } \\
\text { cooked } \\
\text { - Food is a gift }\end{array}$ & $\begin{array}{l}\text { - Cooking mostly } \\
\text { female chore } \\
\text { - Eating and table } \\
\text { manners important } \\
\text { - Husband's } \\
\text { preferences are } \\
\text { cooked } \\
\text { - Healthy eating is } \\
\text { important } \\
\text { - Food is a gift }\end{array}$ & $\begin{array}{l}\text { Sometimes } \\
\text { husbands cook } \\
\text { Health, wholesome } \\
\text { food is important } \\
\text { Food is not self- } \\
\text { evident }\end{array}$ & $\begin{array}{l}\text { - Males cook as well, } \\
\text { yet females cook } \\
\text { more } \\
\text { - Eating is important as } \\
\text { lifes tyle } \\
\text { - Resourcefulness due } \\
\text { to sustainability } \\
\text { - Food is precious, part } \\
\text { of life style }\end{array}$ \\
\hline
\end{tabular}

Table 1: Overview of changes and similarities in meal patterns over three generations.

Int J Clin Nutr Diet

ISSN: 2456-8171
IJCND, an open access journal Volume 3. 2017. 122 
Citation: Brombach C (2017) Meals and Eating Practices within a Multi-generational Approach: A Qualitative Insight Study. Int J Clin Nutr Diet 3: 122. doi: https://doi.org/10.15344/2456-8171/2017/122

Page 5 of 6

both limitations as well as possibilities for improvement of the study. The number of participants is low and the family not representative. Results refer to a cultural pattern in South-West Germany and may therefore not be generalized. There is also an overlap within agegroups in this family, since in the F2 generation there is already an age range from the youngest to the oldest of 22 years. Martha's first grandchild was born just three years after the birth of her youngest child and within the grandchildren there is an age range of 36 years and currently 46 years within the great grandchildren. Hence, differences and transmission patterns might be more related to age than generation.

Even today the female role in preparing and cooking on a daily basis is still a predominantly female task in Germany, as data from the National Nutrition Survey reveal [46]. The findings of other studies [5, 8,15,37] also show that there is a transmission of cooking and eating style from mothers to daughters, Scaglioni et al. [26] revealed in their study an influence of the mothers' behaviours and attitudes on their children.

In general there seems to be a transmission of lunch as the main meal towards dinner time, as can also be shown from the National Nutrition Survey in Germany, which is a representative survey [46], so the findings of this case study are well within general transformation processes in an industrialized country such as Germany.

In a survey on "The Role of Internet Recipes in Cooking" Bartsch et al. [53] found, that despite internet recipes and food blogs "mothers" are still the main source for family recipes, advice of how to cook and the place of learning how to cook. Transmission of cooking skills and family traditions seem to follow predominantly a matrilineal pattern which are likely, however, to diminished. There are several reasons why transmission of cooking skills in a matrilineal way might degrade at present in Germany: females are more engaged in work force, so cooking time and interaction at the time of meal preparation decreases [54], children are eating lunch out of home more often, thus do not experience and learn cooking at home any longer, males are seemingly getting more engaged in cooking and food preparation [55].

Despite the fact that cooking, gardening and house work was highly disregarded during the 70's and seen as an obstacle to women's equality [56], young women and males today seem to be so less inclined and are getting involved again in community projects on cooking, gardening and equally share chores within a partnership. Young men are becoming attracted to food topics and cooking, in this study the males of F4 generation are more involved in cooking or even choose to become a professional cook. Future studies will show if the equal sharing of cooking, gardening and home work between males and females will be maintained. It seems that studies on meals and eating practices have to consider both: family settings as well as cultural contexts [57].

Although results of this exploratory study may not be generalised and should be interpreted with caution, several studies show $[37 ; 38$; 46-51] that parents influence their children's nutritional behaviour. However,todate there are few studies that make links across three generations let alone within a multi-generational approach in a time horizon of almost 100 years.

To date very few studies have been conducted with a three generational, let alone multi-generational approach on tracing eating practices within one family. The findings permit better understanding of the onset of eating practices in a broader familial and cultural historical context. This study, therefore, permits insights into this field and paves the way for a rich diversity of future research topics.

\section{Ethical Approval}

Ethical approval was received by the University Ethic Committee of the University of Jena, Germany, Nr.4707-02/16.

\section{Conflict of Interest}

The author declares no conflict of interest according to the guidelines of the International Committee of Medical Journal Editors. The survey was financed by internal university funding. The present article complements an oral presentation given at the 11th Scientific Congress of Nutrition, Madrid, Spain on 1 July 2017.

\section{Acknowledgements}

The author wants to thank the interview partners for giving their time and sharing insights of their family eating-practices as well as to Stella Cook Zurich University of Applied Sciences Waedenswil who carefully and critically read the manuscript.

\section{References}

1. Köster EP (2009) Diversity in the determinants of food choice: a psychological perspective. Food Quality and Preference 20: 70-82.

2. Bisogni CA, Connors M, Devine CM, Sobal J (2002) Who we are and how we eat: a qualitative study of identities in food choice. Journal of Nutrition Education Behavior 34: 128-139.

3. Shatenstein B, Gauvin L, Keller H, Richard L, Gaudreau P, et al. (2013) Baseline determinants of global diet quality in older men and women from the NUAGE cohort. J Nutr Health Aging 17: 419-425.

4. Berge JM (2009) A review of familial correlates of child and adolescent obesity: what has the 21 century taught us so far? Int J Adolesc Med Health 21: 457-483.

5. Brombach C, Haefeli D, Bartsch S, Clauß S, Winkler G (2014) What have we kept and what have we changed? A three generation study on nutrition and food handling. Ernahrungs Umschau 61: 171-177.

6. Sobal J, Bisogni CA, Devine CM, Jastran M (2006) A conceptual model of the food choice process over the life course. In: Shepherd R, Raats $M$ (Eds.), The Psychology of Food Choice. CABI Publishing, Cambridge MA, pp. 1-18.

7. Sobal J, Khan LK, Bisogni CA (1998) A conceptual model of the food and nutrition system. Social Science and Medicine 47: 853-863.

8. Visser SS, Hutter I, Haisma H (2016) Building a framework for theorybased ethnographies for studying intergenerational family food practices. Appetite 97: 49-57.

9. Birch LL (2016) Learning to Eat: Behavioral and Psychological Aspects. Nestle Nutr Inst Workshop Ser 85: 125-34.

10. Birch LL, Fisher JO (2006) Mothers' child-feeding practices influence daughters' eating and weight. Am J Clin Nutr 71: 1054-1061.

11. Fisher JO, Birch LL (1999) Restricting access to foods and children's eating. Appetite 32: 405-419.

12. Mennella JA, Jagnow CP, Beauchamp GK (2001) Prenatal and postnatal flavor learning by human infants. Pediatrics 107: E88.

13. Addessi E, Galloway AT, Visalberghi E, Birch LL (2005) Specific social influences on the acceptance of novel foods in 2-5-year-old children. Appetite 45: 264-271.

14. Cutting TM, Fisher JO, Grimm-Thomas K, Birch LL (1999) Like mother, like daughter: familial patterns of overweight are mediated by mothers' dietary disinhibition. Am J Clin Nutr 69: 608-613.

15. Rhodes K, Chan F, Prichard I, Coveney J, Ward P, et al. (2016) Intergenerational transmission of dietary behaviours: A qualitative study of Anglo-Australian, Chinese-Australian and Italian-Australian threegeneration families. Appetite 103: 309-17. 
Citation: Brombach C (2017) Meals and Eating Practices within a Multi-generational Approach: A Qualitative Insight Study. Int J Clin Nutr Diet 3: 122. doi:

16. Edstrom KM, Devine CM (2001) Consistency in Women's orientations to food and nutrition in midlife and older age: a 10-year qualitative follow-up. J Nutr Educ 33: 215-223.

17. Atkins JL, Ramsay SE, Whincup PH, Morris RW, Lennon LT, et al. (2015) Diet quality in older age: the influence of childhood and adult socioeconomic circumstances. Br J Nutr 113: 1441-1452.

18. Vabo M, Hansen $H(2014)$ The relationship between food preferences and food choice: a theoretical discussion. International Journal of Business and Social Science 5: 145-157.

19. Vauthier JM, Luch A, Lecomte E, Artur Y, Herbeth B (1996) Family resemblance in energy and macronutrient intakes: The Stanislas Family Study. Int J Epidemiol 25: 1030-1037.

20. Silvermann D (2013) Doing Qualitative Research. London, SAGE.

21. Mayring P (2015) Qualitative Inhaltsanalyse, Handbuch Qualitative Forschung in der Psychologie, pp 601-613.

22. De Almeida MotaRamalho J, Lachal J, Ferro Bucher-Maluschke JSN, Moro MR, Revah-Levy A (2016) A qualitative study of the role of food in family relationsships: an insight into the families of Brazilian obese adolescents using photo elicitation. Appetite 96: 539-545

23. Douglas M, Nicod M (1974) Taking the biscuit: the structure of British meals. New Society 637: 744-747.

24. Just DR, Wansink B (2009) Better school meals on a budget: using behavioural economics and food psychology to improve meal selection. Choices 24: 1-6.

25. Scaglioni S, Salvioni M, Galimberti C (2008) Influence of parental attitudes in the development of children eating behaviour. Br J Nutr 99: S22-S25.

26. https://www.mri.bund.de/en/institutes/nutritional-behaviour

27. Barlösius E (2011) Soziologie des Essens (Sociology of Nutrition) (2. Aufl.), Weinheim \&München, JuventaVerlag.

28. Dean M, Raats MM, Grunert KG, Lumbers M (2009) Factors influencing eating a varied diet in oldage. Public Health Nutr 12: 2421-2427.

29. Goody J (1982) Cooking, cuisine, class. A study on comparative sociology. Cambridge: University Press.

30. Mennell S, Murcott A, van Otterloo AH (1992) The sociology of food: Eating diet and culture, London: Sage.

31. Charles N, Kerr M (1988) Women, Food and Families. Manchester Manchester: University Press.

32. Fischler C (1988) Food, Self and Identity. Soc Sci inform 27: 275-292.

33. Gibney MJ, Wolever TMS (1997) Periodicity of eating and human health: present perspective and future directions. Br J Nutr 77: 3-5.

34. Mennell S (1985) All manners of Food: Eating and taste in England and France from the middle ages to the present. Oxford: Basil Blackwell.

35. Haupt HG, Torp C (eds.), 2010: Die Konsumgesellschaft in Deutschland 1890-1990. EinHandbuch (The Consumption Society in Germany 18901990. A Handbook).Frankfurt a.M.: Campus

36. Snoek HM, van Strien T, Jansens JM, Engels RC (2009) Longitudinal relationships between fathers', mothers', and adolescents' restrained eating. Appetite 52: 461-468.

37. Baker CW, Whisman MA, Brownell KD (2000) Studying intergenerational transmission of eating attitudes and behaviors: methodological and conceptual questions. Health Psychol 19: 376-381.

38. Jahnke DL, Warschburger PA (2008) Familial transmission of eating behaviors in preschool-aged children. Obesity (Silver Spring) 16: 18211825.

39. Dickens E, Ogden J (2014) The role of parental control and modelling in predicting a child's diet and relationship with food after they leave home. A prospective study. Appetite 76: 23-29.

40. Brown R, Ogden J (2004) Children's eating attitudes and behavior: a study of the modelling and control theories of parental influence. Health Educ Res 19: 261-271.

41. Jones A (2016) Intergenerational educational attainment, family characteristics and child obesity. In: J Biosoc Sci 48: 557-576.

42. Stafleu A, van Staveren WA, de Graaf C, Burema J, Hautvast JG.A.J (1994) Family resemblance in energy, fat, and cholesterol intake: A study among three generations of women. Preventive Medicine 23: 474-480.

43. Brown R, Ogden J (2004) Children's eating attitudes and behaviour: a study of the modelling and control theories of parental influence. Health Educ Res 19: 261-271.

44. Silvermann D (2013) Doing Qualitative Research. London: SAGE
45. Haarer L (1977) Kochen und Backennach Grundrezepten (Cooking and Baking basic recipes). 7th edition, Baltsmannsweiler.

46. Max-Rubner-Institut (2008) National Nutrition Survey II.

47. Christian MS, Evans CE, Hancock N, Nykjaer C, Cade JE(2013) Family meals can help children reach their 5 a day: a cross-sectional survey of children's dietary intake from London primary schools. J Epidemiol Community Health 67: 332-338.

48. van der Horst K, Ferrage A, Rytz A (2014) Involving children in meal preparation. Effects on food intake. Appetite 79: 18-24.

49. Fulkerson JA, Story M, Neumark-Sztainer D, Rydell S (2008) Family meals: perceptions of benefits and challenges among parents of 8 - to 10-year-old children. J Am Diet Assoc 108: 706-709.

50. Rollins BY, Loken E, Savage JS, Birch LL (2014) Effects of restriction on children's intake differ by child temperament, food reinforcement, and parent's chronic use of restriction. Appetite 73: 31-39.

51. Galloway AT, Fiorito L, LeeY, Birch LL (2005) Parental pressure, dietary patterns, and weight status among girls who are "picky eaters". J Am Diet Assoc 105: 541-548.

52. Brombach C, Bartsch S, Winkler G (2015) Ernährungsverhalten im Verlaufvon drei Generationen (Nutrition behaviour in threegenerations). Sc hweizerZeitschriftfürErnährungsmedizin 5: 20-25.

53. Bartsch S, Brombach C, Winkler G (2015) The Role of Internet Recipes in Cooking, p. 33-44. In P. Lysaght\& V. Krawczyk-Wasilewska (Hrsg.). Food and the Internet. Frankfurt a. M.: Peter Lang GmbH.

54. https://www.destatis.de/DE/Publikationen/Thematisch/EinkommenKonsum Lebensbedingungen/Zeitbudgeterhebung/TagungsbandWieDieZeitVergeh t5639103169004Kap04.pdf?_blob=publicationFile.

55. https://www.washingtonpost.com/news/wonk/wp/2016/07/19/why-somany-millennial-men-are-cooking/?utm_term=.e7f8169defb0

56. Sellach B (1995) Wie kommt das Essen auf den Familientisch? Frauen berichten ("How does the food get on the table? Women report") Dissertation University of Giessen, Germany 